\title{
Effects of heat stress and dietary zinc source on performance and mammary epithelial integrity of lactating dairy cows
}

\author{
X. Weng, ${ }^{*}$ A. P. A. Monteiro, ${ }^{*}$ J. Guo, ${ }^{*}$ C. Li, $†$ R. M. Orellana, ${ }^{*}$ T. N. Marins, ${ }^{*}$ J. K. Bernard, ${ }^{*}$ \\ D. J. Tomlinson, $\ddagger$ J. M. DeFrain, $\ddagger$ S. E. Wohlgemuth, $\dagger$ and S. Tao*1 \\ *Department of Animal and Dairy Science, University of Georgia, Tifton 31793 \\ †Department of Animal Sciences, University of Florida, Gainesville 32611 \\ ‡Zinpro Corporation, Eden Prairie, MN 55344
}

\section{ABSTRACT}

Dietary $\mathrm{Zn}$ and heat stress alter gut integrity in monogastric animals. However, effects of $\mathrm{Zn}$ on mammary epithelial integrity in heat-stressed lactating dairy cows have not been studied. Multiparous lactating Holstein cows $(\mathrm{n}=72)$ were randomly assigned to 1 of 4 treatments with a $2 \times 2$ factorial arrangement to study the effects of environment and $\mathrm{Zn}$ source on performance and mammary epithelial integrity. Treatments included 2 environments [cooled (CL) or not cooled (NC)] and $2 \mathrm{Zn}$ sources [75 $\mathrm{mg} / \mathrm{kg}$ of supplemental $\mathrm{Zn}$ as Zn hydroxychloride (IOZ) or $35 \mathrm{mg} / \mathrm{kg}$ of $\mathrm{Zn}$ hydroxychloride $+40 \mathrm{mg} / \mathrm{kg}$ of $\mathrm{Zn}$-Met complex $(\mathrm{ZMC})]$. The experiment was divided into baseline and environmental challenge phases of $84 \mathrm{~d}$ each. All cows were cooled during the baseline phase (temperature-humidity index $=72.5$ ), whereas $\mathrm{NC}$ cows were not cooled during environmental challenge (temperature-humidity index $=77.7)$. Mammary biopsies were collected on d 7 and 56 relative to the onset of environmental challenge to analyze gene expression of claudin 1,4 , and 8 , zonula occludens 1, 2, and 3, occludin, and E-cadherin and protein expression of occludin and E-cadherin. Deprivation of cooling increased respiration rate $(64.8$ vs. 73.9 breaths/min) and vaginal temperature (39.03 vs. $39.94^{\circ} \mathrm{C}$ ) and decreased dry matter intake (26.7 vs. $21.6 \mathrm{~kg} / \mathrm{d})$. Energy-corrected milk yield decreased for $\mathrm{NC}$ cows relative to CL cows (24.5 vs. $34.1 \mathrm{~kg} / \mathrm{d})$. An interaction between environment and $\mathrm{Zn}$ source occurred for milk fat content as CL cows fed ZMC had lower milk fat percentage than other groups. Relative to CL cows, NC cows had lower concentrations of lactose (4.69 vs. $4.56 \%$ ) and solids-not-fat (8.46 vs. $8.32 \%$ ) but a higher concentration of milk urea nitrogen $(9.07$ vs. $11.02 \mathrm{mg} / \mathrm{mL}$ ). Compared with IOZ, cows fed ZMC

Received July 11, 2017.

Accepted November 9, 2017.

${ }^{1}$ Corresponding author: stao@uga.edu had lower plasma lactose concentration during baseline and tended to have lower plasma lactose concentration during environmental challenge. Plasma lactose concentration tended to increase at 3,5 , and $41 \mathrm{~d}$ after the onset of environmental challenge in $\mathrm{NC}$ cows relative to CL cows. Treatment had no effect on milk BSA concentration. Cows fed ZMC tended to have higher gene expression of E-cadherin relative to IOZ. Compared with CL, NC cows had increased gene expression of occludin and E-cadherin and tended to have increased claudin 1 and zonula occludens 1 and 2 gene expression in the mammary gland. Protein expression of occludin and E-cadherin was unchanged. In conclusion, removing active cooling impairs lactation performance and affects gene expression of proteins involved in the mammary epithelial barrier, and feeding a portion of dietary zinc as ZMC improves the integrity of the mammary epithelium.

Key words: heat stress, zinc, mammary epithelial junction

\section{INTRODUCTION}

Heat stress (HS) is well known to negatively affect performance of lactating dairy cows. Studies (Shwartz et al., 2009; Wheelock et al., 2010) showed that environmental HS reduced milk production by approximately 30 to $40 \%$ in mid-lactation dairy cows. Although decreased DMI explains approximately half the reduction in milk production (Rhoads et al., 2009; Wheelock et al., 2010), physiological and cellular mechanisms related to reduced milk synthesis by HS in addition to decreased DMI are still unclear. Milk production of the lactating dairy cow is determined by secretory capacity of the mammary gland, including both number and activity of mammary secretory cells (Capuco et al., 2003). Thus, environmental HS may affect the cow's milk production by impairing mammary gland function. In an in vitro study (Collier et al., 2006), mammary epithelial cells underwent increased apoptosis when incubated under high ambient temperature compared with thermal 
neutral conditions, providing evidence that HS directly influences mammary cell abundance.

The intercellular junction complex is a barrier that regulates the movement of molecules and ions through paracellular pathways in both the endothelium and epithelium, including the mammary epithelium (Nguyen and Neville, 1998). During lactation, the mammary epithelium forms a highly impermeable barrier to separate milk and interstitial fluid and to maintain optimal milk synthesis and secretion (Stelwagen and Singh, 2014). In contrast, increased mammary epithelial permeability, caused by extended milking frequency or mastitis, negatively affects normal mammary function and health of lactating dairy cows (Nguyen and Neville, 1998; Stelwagen and Singh, 2014). The effect of environmental HS on epithelial integrity has been the subject of many studies in species other than dairy cattle. For example, under in vitro conditions, HS increased the permeability of canine and porcine kidney epithelial cell junctions and human colon and kidney epithelial junctions (Dokladny et al., 2016). Similarly, in vivo exposure to HS impaired gut integrity in swine (Pearce et al., 2013, 2014; Sanz Fernandez et al., 2014), rodents, and primates (Dokladny et al., 2016). However, the effect of HS on the permeability of the mammary epithelium in lactating dairy cows has never been studied.

In addition to environmental factors, dietary $\mathrm{Zn}$, an essential micronutrient, is important to maintenance of critical body functions such as immunity and metabolism and is thereby critical for animal growth, health, and optimal performance (NRC, 2001). Dietary Zn also improves epithelial integrity and maintains proper tissue function. Sanz Fernandez et al. (2014) reported that increasing dietary Zn concentration from 120 to $220 \mathrm{mg} / \mathrm{kg}$ by supplementation with Zn-AA complex improved the small intestine integrity of growing pigs under HS conditions. However, the role of $\mathrm{Zn}$ in maintaining bovine mammary epithelial integrity is still unknown. The source of dietary Zn may also influence epithelial integrity. Pearce et al. (2015) found that replacing a portion of $\mathrm{ZnSO}_{4}$ with $\mathrm{Zn}-\mathrm{AA}$ complex mitigated the HS-induced reduction in ileum integrity in pigs. In heat-stressed steers, replacing a portion of $\mathrm{ZnSO}_{4}$ with $\mathrm{Zn}-\mathrm{AA}$ complex decreased duodenum villi width and increased both jejunum villi height and ratio of villi height to crypt depth, indicating an improved intestinal barrier function during HS (Abuajamieh et al., 2016). Whether Zn-AA complex has a similarly positive effect compared with inorganic sources on maintaining the integrity of the mammary epithelium in bovines is unclear.

We hypothesized that environmental HS impairs mammary function through increasing the permeability of the mammary epithelium of lactating dairy cows and that replacing a portion of dietary inorganic $\mathrm{Zn}$ with Zn-AA complex would improve the integrity of the mammary epithelium, especially under HS conditions. The objective was to evaluate the effect of environmental $\mathrm{HS}$ and supplementation of different $\mathrm{Zn}$ sources (Zn-Met complex vs. Zn hydroxychloride) on performance and the permeability of the mammary epithelium in lactating Holstein cows.

\section{MATERIALS AND METHODS}

\section{Animals and Experimental Design}

The study was conducted at the Dairy Research Center of the University of Georgia, Tifton campus, from April to September 2015. Procedures and animal handling were approved by the University of Georgia Institutional Animal Care and Use Committee before trial initiation.

Seventy-two multiparous lactating Holstein cows were blocked by parity $(2.9 \pm 0.3)$ and DIM (99.7 \pm $13.4 \mathrm{~d}$ ) and then assigned randomly to 1 of 4 treatments within block in a $2 \times 2$ factorial arrangement: (1) diet supplemented with $75 \mathrm{mg} / \mathrm{kg}$ of $\mathrm{Zn}$ as Zn hydroxychloride (IOZ; Micronutrients, Indianapolis, IN) with cooling ( $\mathbf{C L} ; \mathrm{n}=18)$, (2) IOZ without cooling (NC; $\mathrm{n}=18)$, (3) diet supplemented with $35 \mathrm{mg} / \mathrm{kg}$ of $\mathrm{Zn}$ as $\mathrm{Zn}$ hydroxychloride and $40 \mathrm{mg} / \mathrm{kg}$ as Zn-Met complex (ZMC; Zinpro Corp., Eden Prairie, MN) with CL $(\mathrm{n}=18)$, and (4) ZMC with NC ( $=18)$. During the course of the experiment, 7 animals were excluded from the trial- 1 cow from the IOZ CL group due to a leg problem, 3 cows from the IOZ NC group due to toxic mastitis and indigestion, 1 cow from the ZMC CL group due to indigestion, and 2 cows from the ZMC NC group due to ketosis and indigestion. Cows were housed in adjacent $\mathrm{CL}$ and $\mathrm{NC}$ pens in the same barn according to their environmental treatment. All animals were fed the same diet except for dietary Zn sources (Table 1 ). The dose of supplemental $\mathrm{Zn}$ was selected based on Nayeri et al. (2014), who reported that replacing 66.6 $\mathrm{mg} / \mathrm{kg}$ of $\mathrm{ZnSO}_{4}$ with $\mathrm{Zn}-\mathrm{AA}$ complex in the dry cow diet and $40 \mathrm{mg} / \mathrm{kg}$ of $\mathrm{ZnSO}_{4}$ with $\mathrm{Zn}-\mathrm{AA}$ complex in the lactating cow diet $(75 \mathrm{mg} / \mathrm{kg}$ of total supplemental Zn) increased milk yield and reduced SCC in multiparous lactating cows. This experiment was divided into a baseline phase and a subsequent environmental challenge phase of $84 \mathrm{~d}$ each. All cows were cooled during the baseline phase, whereas during the environmental challenge phase NC cows were not cooled. The cooling system included misters attached to the front face of fans over feed bunks and freestalls. Fans (0.9-m diameter) were located at 6-m intervals over feedline and freestalls and provided at least $9.5 \mathrm{~km} / \mathrm{h}$ wind speed at 
the cow level. Fans ran continuously when the environmental temperature was $\geq 20^{\circ} \mathrm{C}$, and continuous misters were activated whenever ambient relative humidity was less than $85 \%$. The onset of the environmental challenge phase was considered to be $\mathrm{d} 1$ of the experiment.

\section{Sample Collection and Analyses}

Environment and Body Temperature. Barn air temperature and relative humidity $(\mathrm{RH})$ were monitored by Hobo Pro Series Temp probes (Onset Computer Corp., Pocasset, MA) every 15 min throughout the experiment, and temperature-humidity index (THI) was calculated based on THI $=(1.8 \times \mathrm{T}+$ $32)-[(0.55-0.0055 \times \mathrm{RH}) \times(1.8 \times \mathrm{T}-26)]$, where $\mathrm{T}=$ air temperature $\left({ }^{\circ} \mathrm{C}\right.$; Dikmen and Hansen, 2009). Respiration rate was counted $(1500 \mathrm{~h})$ for all cows once each week during the baseline phase and then 3 times each week during the environmental challenge phase. Vaginal temperature was monitored every 5 min for 4 continuous days using an ibutton (Mouser Electronics, Mansfield, TX) attached to a blank controlled internal drug release every 2 wk during the baseline phase and then each week during the environmental challenge phase in a subset of cows ( $\mathrm{n}=16 /$ treatment).

Feed Intake, Sample Collections, BW, and $\boldsymbol{B} \boldsymbol{C S}$. Cows were fed once daily $(1300 \mathrm{~h})$, with daily feed intake measured using a Calan Broadbent feeding system (American Calan Inc., Northwood, NH) throughout the experiment. Individual dietary ingredients and TMR were sampled 3 times each week (Monday, Wednesday, and Friday). The DM content of samples was measured by drying at $55^{\circ} \mathrm{C}$ for $48 \mathrm{~h}$ in a forced-air oven. Rations were adjusted as needed based on changes in ingredient DM content. Samples of TMR were composited every $2 \mathrm{wk}$ and ground to pass through a 1-mm screen using a Wiley mill (Thomas Scientific, Swedesboro, NJ) for nutrient analysis (Table 2) by Dairyland Laboratories (Arcadia, WI). Drinking water was sampled for mineral and hardness analyses at 2 and $5 \mathrm{mo}$ after the onset of the experiment at different watering locations within pens (Table 3) by Dairyland Laboratories (Arcadia, WI). Water sampling procedures provided by Dairyland Laboratories were followed. Body weight was recorded every $2 \mathrm{wk}$, and BCS was assigned (Wildman et al., 1982) throughout the entire experiment.

Milk and Blood Samples. Cows were milked 3 times $(0800,1600$, and $2400 \mathrm{~h}$ ) each day, and milk yield was recorded at each milking (Alpro, DeLaval, Kansas City, MO). Milk samples were collected from 3 consecutive milkings each week with bronopol-B-14 as a preservative for analyses of milk components (fat, protein, lactose, SNF, MUN, and SCC; Dairy One Co-
Table 1. Ingredient composition of experimental diets

\begin{tabular}{|c|c|}
\hline Ingredient & $\%$ of DM \\
\hline Corn silage & 24.68 \\
\hline Ryegrass silage & 16.45 \\
\hline Ryegrass hay & 3.29 \\
\hline Brewers grains, wet & 11.10 \\
\hline Ground corn & 19.74 \\
\hline Molasses & 4.94 \\
\hline Soybean hulls & 1.65 \\
\hline Citrus pulp & 6.58 \\
\hline Soybean meal & 1.65 \\
\hline Amino Plus ${ }^{1}$ & 2.06 \\
\hline Prolak $^{2}$ & 3.04 \\
\hline Metabolys ${ }^{3}$ & 0.44 \\
\hline Mepron ${ }^{4}$ & 0.07 \\
\hline Megalac $^{5}$ & 1.65 \\
\hline Salt & 0.04 \\
\hline Calcium carbonate & 0.49 \\
\hline Sodium bicarbonate & 0.82 \\
\hline Magnesium oxide & 0.28 \\
\hline Dynamate $^{6}$ & 0.08 \\
\hline Rumensin ${ }^{7}$ & 0.25 \\
\hline OmniGen-AF ${ }^{8}$ & 0.20 \\
\hline Diamond $\mathrm{V} \mathrm{XP}{ }^{9}$ & 0.21 \\
\hline Trace mineral-vitamin premix $^{10}$ & 0.30 \\
\hline
\end{tabular}

${ }^{1}$ Ruminally protected soybean meal (Ag Processing Inc., Omaha, NE).

${ }^{2}$ Marine and animal RUP supplement (H. J. Baker \& Bros. Inc., Westport, CT).

${ }^{3}$ Ruminally protected bypass lysine (H. J. Baker \& Bros. Inc.).

${ }^{4}$ Rumen-protected methionine (Evonik Industries, Kennesaw, GA).

${ }^{5}$ Calcium salts of long-chain FA (Arm \& Hammer Animal Nutrition, Church \& Dwight Co. Inc., Princeton, NY).

${ }^{6}$ Feed-grade mineral consisting of sulfate form of potassium and magnesium (Mosaic Co. Inc., Plymouth, MN).

${ }^{7}$ Rumensin (Elanco Animal Health, Indianapolis, IN).

${ }^{8}$ Immune stimulant (Phibro Animal Health Corp., Teaneck, NJ).

${ }^{9}$ Microbio product containing active enzymes derived from the microorganisms Aspergillus oryzae, Aspergillus niger, and Trichoderma viride and selected microorganisms: Propionibacterium freudenreichii, Lactobacillus acidophilus, Lactobacillus casei, Enterococcus faecium, Lactobacillus lactis, Pediococcus cerevisiae, Bacillus subtilis, Bacillus licheniformis, and Aspergillus oryzae. Diamond V. Inc. (Cedar Rapids, IA).

${ }^{10}$ Mineral-vitamin premix contained (DM basis) $75.63 \%$ calcium carbonate; 5.03\% Sel Plex 2000 (Alltech, Lexington, KY); 4.70\% IntelliBond M (Micronutrients, Indianapolis, IN); $3.90 \%$ Avalia Mn 80 (Zinpro Corp., Eden Prairie, MN); $2.42 \%$ IntelliBond Z (Micronutrients; providing approximately $35 \mathrm{mg} / \mathrm{kg}$ of $\mathrm{Zn}$ of total DMI); $1.95 \% \mathrm{Availa} \mathrm{Cu}$ (Zinpro Corp.); $1.51 \%$ Copro 25 (Zinpro Corp.); 0.28\% copper chloride; $0.05 \%$ ethylenediamine dihydroiodide; $2.74 \%$ vitamin $\mathrm{E}, 227,000$ IU $(13,869 \mathrm{IU} / \mathrm{kg}) ; 1.82 \%$ vitamin A, 325,000 (6,004,570 IU/kg); vitamin D $(600,430 \mathrm{IU} / \mathrm{kg})$. The rest of $\mathrm{Zn}[0.007 \%$ IntelliBond $\mathrm{Z}$ and $0.033 \%$ Zinpro 120 (Zinpro Corp.) relative to the total ration of DM of cows receiving $\mathrm{Zn}$ hydroxychloride and $\mathrm{Zn}$-Met complex, respectively] was hand added to diets.

operative, Ithaca, NY) using a Foss 4000 instrument (Foss North America, Eden Prairie, MN). Additional milk samples were collected without a preservative from 3 consecutive milkings at d $-88,-74,-46,-18$, $-3,1,3,5,18,25,39,53$, and 67 and stored at $-20^{\circ} \mathrm{C}$ for milk BSA analysis. Milk BSA concentration was analyzed using a colorimetric method with bromocresol green dye (Sigma-Aldrich, St. Louis, MO) described 
Table 2. Nutrient content (mean \pm SD) of experimental diets supplemented with Zn hydroxychloride (IOZ) or Zn-Me complex (ZMC)

\begin{tabular}{|c|c|c|}
\hline DM basis & $\operatorname{IOZ}(\mathrm{n}=12)$ & $\mathrm{ZMC}(\mathrm{n}=12)$ \\
\hline $\mathrm{CP}, \%$ & $17.9 \pm 0.8^{1}$ & $18.3 \pm 1.0$ \\
\hline Soluble protein, $\%$ of CP & $38.8 \pm 3.4$ & $41.3 \pm 2.6$ \\
\hline Ash-free NDF, \% & $30.0 \pm 1.4$ & $30.0 \pm 1.6$ \\
\hline $\mathrm{ADF}, \%$ & $20.7 \pm 1.2$ & $20.2 \pm 0.7$ \\
\hline Lignin, \% & $3.0 \pm 0.4$ & $2.7 \pm 0.2$ \\
\hline Starch, \% & $24.3 \pm 1.7$ & $23.9 \pm 2.3$ \\
\hline Sugar, $\%$ & $4.4 \pm 0.8$ & $5.4 \pm 0.9$ \\
\hline Ether extract, \% & $4.7 \pm 0.3$ & $4.7 \pm 0.3$ \\
\hline $\mathrm{NFC}, \%$ & $41.6 \pm 1.6$ & $41.1 \pm 1.1$ \\
\hline Ash, $\%$ & $8.5 \pm 0.9$ & $8.8 \pm 0.9$ \\
\hline $\mathrm{NE}_{\mathrm{L}}, \mathrm{Mcal} / \mathrm{kg}$ & $1.64 \pm 0.03$ & $1.64 \pm 0.03$ \\
\hline Calcium, $\%$ & $1.2 \pm 0.3$ & $1.3 \pm 0.3$ \\
\hline Phosphorus, \% & $0.5 \pm 0.0$ & $0.5 \pm 0.0$ \\
\hline Magnesium, \% & $0.4 \pm 0.0$ & $0.4 \pm 0.0$ \\
\hline Potassium, \% & $1.7 \pm 0.2$ & $1.8 \pm 0.2$ \\
\hline Sulfur, $\%$ & $0.3 \pm 0.0$ & $0.3 \pm 0.0$ \\
\hline Sodium, \% & $0.4 \pm 0.1$ & $0.4 \pm 0.1$ \\
\hline Chloride, \% & $0.5 \pm 0.1$ & $0.5 \pm 0.1$ \\
\hline Manganese, $\mathrm{mg} / \mathrm{kg}$ & $136.8 \pm 29.3$ & $134.6 \pm 31.5$ \\
\hline Zinc, $\mathrm{mg} / \mathrm{kg}$ & $154.9 \pm 25.6$ & $156.4 \pm 24.9$ \\
\hline Copper, mg/kg & $17.8 \pm 5.8$ & $16.9 \pm 3.0$ \\
\hline Iron, $\mathrm{mg} / \mathrm{kg}$ & $550.9 \pm 61.8$ & $535.6 \pm 39.9$ \\
\hline Molybdenum, mg/kg & $1.8 \pm 0.6$ & $1.6 \pm 0.2$ \\
\hline Cobalt, $\mathrm{mg} / \mathrm{kg}$ & $1.4 \pm 0.2$ & $1.4 \pm 0.2$ \\
\hline
\end{tabular}

by Lieske et al. (2005) with inter- and intra-assay coefficients of variation of 5.2 and $2.9 \%$. Briefly, milk samples were pooled by day proportional to milk yield at each milking and centrifuged at 3,000 $\times g$ for $15 \mathrm{~min}$ at $4^{\circ} \mathrm{C}$ to obtain skim milk. A master mix made from bromocresol green dye, succinic acid (Thermo Fisher Scientific, Waltham, MA), and Brij-35 (30\%; Thermo Fisher Scientific) was used in the colorimetric assay. A skim milk sample $(200 \mu \mathrm{L})$ was fully mixed with $900 \mu \mathrm{L}$ of master mix and centrifuged at 1,900 $\times g$ for $10 \mathrm{~min}$ at $25^{\circ} \mathrm{C}$. Supernatant $(150 \mu \mathrm{L})$ was transferred to a $96-$

Table 3. Composition, $\mathrm{pH}$, and hardness of the drinking water at mo 2 and 5 after onset of the experiment

\begin{tabular}{lcc}
\hline Item & mo 2 & mo 5 \\
\hline $\mathrm{pH}$ & 7.76 & 7.87 \\
Hardness, mg/kg & 172 & 150 \\
Composition, mg/kg & & \\
Nitrate & 1.30 & 1.55 \\
Calcium & 53.60 & 47.67 \\
Magnesium & 9.28 & 7.47 \\
Phosphorus & 0.12 & $<0.01$ \\
Potassium & 1.32 & 1.04 \\
Copper & 0.03 & 0.01 \\
Iron & 0.08 & 0.04 \\
Zinc & 0.13 & 0.03 \\
Sodium & 4.15 & 4.06 \\
Manganese & 0.03 & 0.01 \\
Chloride & $<8$ & 7 \\
Sulfates & 2.25 & 1.77 \\
Total dissolved solids & 220 & 295 \\
\hline
\end{tabular}

Journal of Dairy Science Vol. 101 No. 3, 2018 well plate to measure the absorbance at $640 \mathrm{~nm}$. The BSA concentrations in skim milk were then calculated based on a standard curve. The BSA concentrations in whole milk were calculated based on the following formula:

\section{BSA (in whole milk; $\mathrm{mg} / \mathrm{g}$ ) = \\ $\left(\right.$ BSA in skim milk $\left./ d_{20^{\circ} \mathrm{C}}\right) /(100-$ fat $) \times 100$,}

where $\mathrm{d}_{20^{\circ} \mathrm{C}}=$ skim milk density of each pooled sample at $20^{\circ} \mathrm{C}(\mathrm{g} / \mathrm{mL})=100 /(\mathrm{F} / 0.93+\mathrm{SNF} / 1.608+$ water \%) $($ Chandan, 2006); fat $=$ fat concentration in whole milk from the results of milk component analysis; $\mathrm{F}$ $=$ fat concentration in skim milk considered as $0.2 \%$ (Pereira, 2014); SNF = SNF concentration in skim milk from the milk component analysis; and water $\%=$ water concentration in skim milk subtracted from skim milk fat and SNF concentrations.

Blood samples were collected from coccygeal vessels into sodium-heparinized Vacutainers (Becton Dickinson, Franklin Lakes, NJ) before feeding $(\sim 1230 \mathrm{~h})$ on $\mathrm{d}-86,-73,-45,-17,-3,1,3,5,12,26,41,54$, and 68 from a subset of animals $(\mathrm{n}=6,5,5$, and 7 for IOZ CL, IOZ NC, ZMC CL, and ZMC NC, respectively). Samples were immediately put in ice and then centrifuged at $2,619 \times g$ for $30 \mathrm{~min}$ at $4^{\circ} \mathrm{C}$ to collect plasma. Colorimetric methods were used to measure plasma lactose concentration using a commercially available kit (BioVision, Milpitas, CA) with inter- and intra-assay coefficients of variation of 3.5 and $1.9 \%$, respectively.

Mammary Biopsy Collections. Mammary biopsies were collected at enrollment as baseline samples and on $\mathrm{d} 7$ and 56 relative to the onset of environmental challenge from a subset of animals ( $\mathrm{n}=8$ /treatment). After the first biopsy collection, 1 animal from ZMC $\mathrm{NC}$ was excluded from the trial due to ketosis-related indigestion. One quarter of another animal from ZMC $\mathrm{NC}$ automatically dried, and this animal was excluded from following tissue collection as well. The first and third biopsies were collected from the left rear quarter, and the right rear quarter was subjected to the second biopsy collection. Procedures for biopsy collection followed the method reported by Farr et al. (1996). Briefly, cows were sedated by intravenous injection of xylazine hydrochloride $(20 \mu \mathrm{g} / \mathrm{kg}$ of BW; Phoenix Pharmaceuticals, St. Joseph, MO). The region for biopsy collection in the midpoint of the quarter was shaved and then sanitized 3 times by scrubbing with iodine followed by rinsing with $70 \%$ ethanol. Local anesthesia was achieved with subcutaneous injection of 3 $\mathrm{mL}$ of lidocaine hydrochloride (Animal Rx Pharmacy, Atlanta, GA) administered in a line block above the biopsy collection site. A 3- to 4-cm incision was made 
HEAT STRESS AND DIETARY ZINC ON MAMMARY TIGHT JUNCTION

Table 4. Names, symbols, GenBank accession numbers, primer sequences, and amplicon sizes of genes examined

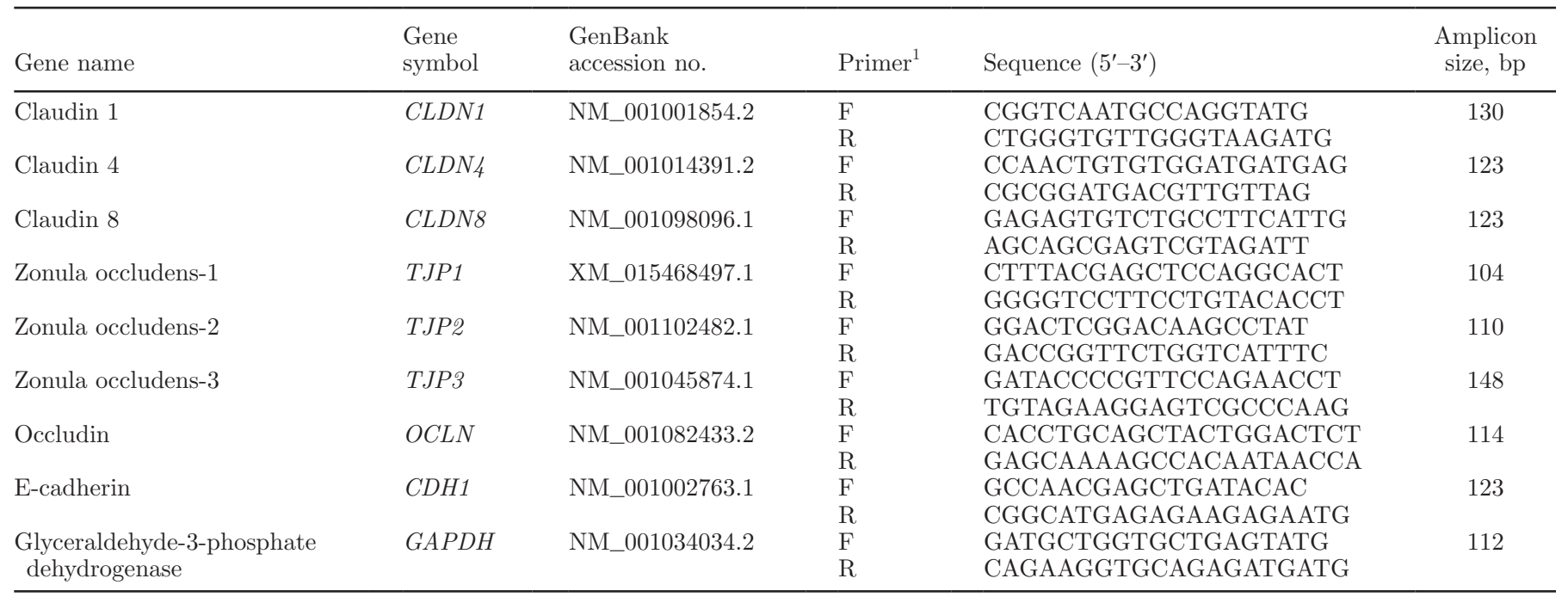

${ }^{1} \mathrm{~F}=$ forward; $\mathrm{R}=$ reverse.

through the skin and connective tissue, avoiding any large subcutaneous blood vessels. A core of mammary tissue $(\sim 0.75 \mathrm{~g})$ was obtained using a rotating stainless steel cannula with a retractable blade connected to a cordless drill (Farr et al., 1996). Incisions were then closed using 18-mm stainless steel Michel wound clips (GerMedUSA, Garden City Park, NY) and administered with an aerosol bandage (Neogen Corp., Lexington, KY) to prevent infection. Tissue was rinsed with PBS, trimmed of fat, separated, and stored in liquid nitrogen and RNAlater (Qiagen, Valencia, CA) for Western blotting and real-time quantitative reverse transcription (RT) PCR analyses, respectively.

RNA Extraction, cDNA Synthesis, and Quantitative $\boldsymbol{R T}$-PCR. Mammary gland tissue was ground in liquid nitrogen, and the total RNA was extracted using TRI-reagent solution (Sigma-Aldrich) and a PureLink RNA mini kit (Invitrogen, Carlsbad, CA) with an on-column DNase (PureLink DNase Set, Invitrogen) treatment following the manufacturer's instructions. A second DNase treatment was performed on the purified RNA extract using a Turbo DNA-free kit (Invitrogen) according to the manufacturer's instructions. The cDNA was synthesized using a high-capacity cDNA reverse transcription kit with RNase inhibitor (Applied Biosystems, Foster City, CA).

Relative quantitative RT-PCR was used to examine gene expression of claudin 1,4 , and 8 , zonula occludens (ZO) 1, 2, and 3, occludin, and E-cadherin in mammary biopsies. Primers were designed using PrimerQuest (Integrated DNA Technologies, Coralville, IA) and are shown in Table 4. The quantitative RT-PCR was carried out using the SYBR green supermix (BioRad, Hercules, CA) in a LightCycler 480 instrument (Roche,
Florence, SC) following the manufacturer's instructions. The cDNA from $50 \mathrm{ng}$ of purified RNA was used for each reaction under the following conditions: $95^{\circ} \mathrm{C}$ for $5 \mathrm{~min}$ for initial denaturation and enzyme activation, 40 cycles of $95^{\circ} \mathrm{C}$ for $15 \mathrm{~s}$, and $57^{\circ} \mathrm{C}$ for $30 \mathrm{~s}$ for amplification. The GAPDH was used as a housekeeping gene. The $2^{-\Delta \Delta \mathrm{CT}}$ method $(\mathrm{CT}=$ threshold cycle) was used to calculate the relative gene expression with data of samples collected at enrollment (baseline sample) as calibrator samples.

Protein Extraction and Western Blotting Analysis. Tissue samples were homogenized in $1 \times$ PBS buffer $\left(137 \mathrm{~m} M \mathrm{NaCl}, 2.7 \mathrm{~m} M \mathrm{KCl}, 8 \mathrm{~m} M \mathrm{Na}_{2} \mathrm{HPO}_{4}, 2\right.$ $\left.\mathrm{mM} \mathrm{KH_{2 }} \mathrm{PO}_{4} ; \mathrm{pH}=7.4\right)$ for 1 min on ice slurry using a Polytron PT 2100 (Kinematica, Littau-Lucerne, Switzerland). The homogenate was kept on ice slurry for 1 $\mathrm{h}$ and then centrifuged at $3,500 \times \mathrm{g}$ for $10 \mathrm{~min}$ at $4^{\circ} \mathrm{C}$. The supernatant was collected and protein concentration was determined using the Bradford protein assay (BioRad). Supernatants were then stored at $-80^{\circ} \mathrm{C}$ for future Western blotting analysis.

Samples were thawed and diluted in Laemmli buffer (BioRad) containing $5 \%$ of $\beta$-mercaptoethanol (SigmaAldrich) with a dilution of 11 parts of sample plus 4 parts of buffer and then boiled for $10 \mathrm{~min}$ at $95^{\circ} \mathrm{C}$. Diluted samples containing 30 or $15 \mu \mathrm{g}$ of protein were loaded on an Any kD TGX precast gel (BioRad) for occludin and E-cadherin protein expression analysis, respectively, with $\beta$-actin as a loading control. The same cross-sample was loaded in each gel for data normalization to minimize gel-to-gel variation. After electrophoretic separation, proteins were transferred to a polyvinylidene difluoride membrane (Millipore, Bedford, MA) using a semidry blotter (BioRad) at $20 \mathrm{~V}$ 
for $1 \mathrm{~h}$. Transferred proteins were subsequently stained with Ponceau S (Sigma-Aldrich) to evaluate quality of protein transfer. The membrane was then blocked for $40 \mathrm{~min}$ at room temperature in TBST $[1 \times$ Trisbuffered saline $(150 \mathrm{mM} \mathrm{NaCl}, 20 \mathrm{~m} M$ TrisBase; $\mathrm{pH}=$ 7.4) with $0.05 \%$ Tween-20 (Fisher Scientific, Hampton, $\mathrm{NH}$ )] containing $5 \%$ nonfat dry milk (BioRad) for occludin and $\beta$-actin detection and 5\% BSA (Millipore) for E-cadherin detection. The blocking step was followed by an overnight incubation at $4^{\circ} \mathrm{C}$ with primary antibody solution. Mouse anti-occludin (Invitrogen; 1:500, diluted in 5\% nonfat dry milk), rabbit anti-Ecadherin (Cell Signaling, Danvers, MA; 1:1,000, diluted in $5 \%$ BSA), and mouse anti- $\beta$-actin (Sigma-Aldrich; 1:32,000, diluted in 5\% nonfat dry milk) were used as primary antibodies. All primary antibodies were tested to cross-react with bovine species. After primary antibody incubation, membranes were washed in TBST buffer and incubated for $1 \mathrm{~h}$ at room temperature with anti-mouse horseradish peroxidase-conjugated secondary antibody (Sigma-Aldrich; 1:16,000, diluted in 5\% nonfat dry milk) for occludin, anti-rabbit horseradish peroxidase conjugated secondary antibody (Cell Signaling; 1:2,000, diluted in 5\% nonfat dry milk) for E-cadherin, and anti-mouse alkaline phosphatase conjugated secondary antibody (Sigma-Aldrich; 1:60,000, diluted in $5 \%$ nonfat dry milk) for $\beta$-actin. The chemiluminescent substrate (Duolux, Vector Laboratories, Burlingame, CA) for horseradish peroxidase or alkaline phosphatase, respectively, was applied according to the manufacturer's recommendation, and the chemiluminescent signal was visualized using a cooled charge-coupled device camera and acquisition software (G-BOX imaging system; Syngene, Frederick, MD). The chemiluminescence intensity was analyzed and quantified by densitometry using the manufacturer's analysis software (GeneTools, Syngene). Band intensity was normalized by the cross-sample run in the same gel. After normalization, the ratio of band intensity of each protein to loading control ( $\beta$-actin) was calculated and used for data analysis, with the baseline sample as a covariate.

Data Analysis. We used PROC UNIVARIATE of SAS 9.4 (SAS Institute Inc., Cary, NC) to calculate means \pm standard deviation of THI. Parity and DIM were analyzed by PROC GLM of SAS 9.4, and the least squares means \pm standard error of the mean are reported. Repeated-measures data (DMI, vaginal temperature, respiration rate, milk yield and composition, plasma lactose concentration, and milk BSA concentration) were analyzed by the PROC MIXED procedure of SAS 9.4. The SAS models included block, cooling, Zn source, time, and their respective interactions, with cow nested within treatment as the random variable. For milk yield analysis, average milk yield of cows before onset of the experiment was included in the model as a covariate. For analyses of plasma lactose and milk BSA concentrations, data obtained at $-86 \mathrm{~d}$ were included in the model as covariates. Gene and protein expression data were analyzed by PROC MIXED of SAS 9.4. The SAS models included block, cooling, Zn source, time, and their respective interactions, with cow nested within treatment as the random variable. The protein expression data obtained from mammary biopsies collected at enrollment were included in the SAS models as covariates. Least squares means \pm standard error of the mean are reported.

\section{RESULTS}

\section{Thermal Environment, Vaginal Temperature, and Respiration Rate}

The average THI in the CL and NC pens was 72.7 $(\mathrm{SD}=5.3)$ and $72.3(\mathrm{SD}=5.3)$, respectively, during the baseline phase and 77.6 $(\mathrm{SD}=3.8)$ and $77.8(\mathrm{SD}=$ 3.8 ), respectively, during the environmental challenge phase, suggesting that all animals were exposed to similar environmental HS throughout the study. During the baseline phase, all cows had similar $(P \geq 0.47)$ vaginal temperature and respiration rate (Table 5). During the environmental challenge phase, regardless of Zn source, CL cows had lower $(P<0.01)$ vaginal temperature $\left(39.03\right.$ vs. $\left.39.94^{\circ} \mathrm{C} ; \mathrm{SEM}=0.05^{\circ} \mathrm{C}\right)$ and respiration rate $(64.8$ vs. 73.9 breaths/min; $\mathrm{SEM}=1.3$ breaths/ min) compared with $\mathrm{NC}$ cows. These results indicate that cooling was effective for reducing cows' heat load (Table 6). No differences $(P \geq 0.20)$ were observed for $\mathrm{Zn}$ or $\mathrm{Zn} \times$ cooling interactions on vaginal temperature or respiration rate (Table 6 ).

\section{Milk Yield and Composition}

During both baseline and environmental challenge phases, dietary Zn source had no $(P \geq 0.12)$ effect on milk yield, SCS, and concentration or yield of milk lactose, protein, SNF, and MUN (Tables 5 and 6). However, relative to cows fed IOZ, cows fed ZMC had a lower $(P=0.05)$ milk fat percentage, resulting in lower $(P=0.03)$ fat yield during the baseline phase (Table 5). During the environmental challenge phase, regardless of Zn source, $\mathrm{NC}$ cows had lower $(P \leq 0.04)$ milk yield, FCM, ECM, and concentration and yield of milk lactose and SNF but higher concentration of MUN compared with CL cows (Table 6). Milk SCS and concentration of protein were not affected $(P \geq 0.80)$ by cooling treatment (Table 6$)$. However, due to lower milk yield, NC cows had lower $(P<0.01)$ milk protein 
perature of dairy cattle during the transition period (Nayeri et al., 2014). In contrast, diets containing 60 $\mathrm{mg} / \mathrm{kg}$ of Zn-AA complex and $60 \mathrm{mg} / \mathrm{kg}$ of $\mathrm{ZnSO}_{4}$ reduced gilts' body temperature during a short-term heat challenge compared with diets supplemented with 120 $\mathrm{mg} / \mathrm{kg}$ of $\mathrm{ZnSO}_{4}$ (Pearce et al., 2015). Mechanisms for possible regulatory effects of $\mathrm{Zn}$ on thermal regulation are unclear. In the current study, no differences were observed between IOZ and ZMC for body temperature or respiration rate, indicating that replacing a portion of Zn hydroxychloride with Zn-Met complex had no effect on cows' thermal regulation under HS in the current experiment.

As expected, NC cows had $27 \%$ lower milk yield and consumed $19 \%$ less DM compared with CL cows, which is consistent with previous research indicating that HS compromises cow performance (Kadzere et al., 2002; West, 2003). Relative to CL cows, NC cows had lower feed efficiency, suggesting that the decrease in DMI cannot entirely explain the loss of milk yield by HS, consistent with previous studies (Rhoads et al., 2009; Wheelock et al., 2010). Environmental conditions had no effect on milk protein percentage in the current study. The effect of HS on milk protein concentration is not consistently reported. Compared with thermo- neutrality, HS reduced milk protein concentration (Rhoads et al., 2009; Shwartz et al., 2009; Wheelock et al., 2010). In contrast, supplementation of evaporative cooling either decreased (Tarazón-Herrera et al., 1999) or had no influence on milk protein content (Taylor et al., 1991; Chen et al., 1993; Chan et al., 1997). These discrepancies between studies may result from different experimental models or distinct basal diets or both. Relative to CL cows, NC cows had lower milk lactose concentrations, which is consistent with previous reports (Shwartz et al., 2009) and suggests that HS reduces mammary lactose synthesis. However, when all cows are offered a similar amount of DM, HS cows have similar milk lactose percentage compared with those under thermoneutrality (Rhoads et al., 2009), indicating that the reduced milk lactose synthesis by HS may depend on feed intake. Similar to results reported by Rhoads et al. (2009) and Shwartz et al. (2009) that HS increases plasma urea nitrogen concentrations compared with thermoneutrality, in the current study, NC cows had higher MUN concentration than CL cows. Reasons for the increased concentrations of BUN or MUN resulting from HS are unknown but may reflect altered ruminal $\mathrm{N}$ metabolism or systemic AA metabolism (Rhoads et al., 2009). Deprivation of cooling had no effect on milk

Table 6. Vaginal temperature, respiration rate, BW, BCS, DMI, feed efficiency, milk yield, and composition of cows fed diets with Zn hydroxychloride (IOZ) or Zn-Met complex (ZMC) either exposed to cooling (CL) or not exposed to cooling (NC) during the environmental challenge phase

\begin{tabular}{|c|c|c|c|c|c|c|c|c|}
\hline \multirow[b]{2}{*}{ Parameter } & \multicolumn{2}{|c|}{ IOZ } & \multicolumn{2}{|c|}{$\mathrm{ZMC}$} & \multirow[b]{2}{*}{ SEM } & \multicolumn{3}{|c|}{$P$-value } \\
\hline & CL & $\mathrm{NC}$ & $\mathrm{CL}$ & $\mathrm{NC}$ & & $\mathrm{Zn}$ & CL & $\mathrm{Zn} \times \mathrm{CL}$ \\
\hline Vaginal temperature, ${ }^{\circ} \mathrm{C}$ & 39.06 & 39.88 & 39.00 & 40.00 & 0.07 & 0.64 & $<0.01$ & 0.20 \\
\hline Respiration rate, breaths/min & 64.4 & 72.4 & 65.3 & 75.5 & 1.8 & 0.28 & $<0.01$ & 0.55 \\
\hline $\mathrm{BW}, \mathrm{kg}$ & 712 & 666 & 711 & 662 & 6 & 0.59 & $<0.01$ & 0.78 \\
\hline BCS & 2.88 & 2.76 & 2.91 & 2.73 & 0.04 & 0.97 & $<0.01$ & 0.48 \\
\hline DMI, kg/d & $27.3^{\mathrm{a}}$ & $21.0^{\mathrm{b}}$ & $26.1^{\mathrm{a}}$ & $22.1^{\mathrm{b}}$ & 0.7 & 0.92 & $<0.01$ & 0.08 \\
\hline Milk yield, kg/d & 35.5 & 25.9 & 35.3 & 25.8 & 1.1 & 0.91 & $<0.01$ & 0.97 \\
\hline $3.5 \% \mathrm{FCM}^{1}, \mathrm{~kg} / \mathrm{d}$ & 35.5 & 25.0 & 33.3 & 24.6 & 1.0 & 0.18 & $<0.01$ & 0.36 \\
\hline $\mathrm{ECM},{ }^{2} \mathrm{~kg} / \mathrm{d}$ & 35.1 & 24.7 & 33.1 & 24.3 & 1.0 & 0.23 & $<0.01$ & 0.40 \\
\hline Feed efficiency ${ }^{3}$ & 1.28 & 1.18 & 1.28 & 1.14 & 0.04 & 0.64 & $<0.01$ & 0.52 \\
\hline \multicolumn{9}{|l|}{ Milk composition } \\
\hline Lactose, \% & 4.70 & 4.57 & 4.67 & 4.55 & 0.05 & 0.61 & $<0.01$ & 0.94 \\
\hline Lactose, $\mathrm{kg} / \mathrm{d}$ & 1.68 & 1.17 & 1.66 & 1.15 & 0.06 & 0.67 & $<0.01$ & 1.00 \\
\hline Protein, $\%$ & 2.86 & 2.86 & 2.81 & 2.85 & 0.05 & 0.57 & 0.80 & 0.70 \\
\hline Protein, kg/d & 1.02 & 0.73 & 0.99 & 0.71 & 0.03 & 0.37 & $<0.01$ & 0.93 \\
\hline Fat, $\%$ & $3.49^{\mathrm{ac}}$ & $3.34^{\mathrm{abc}}$ & $3.14^{\mathrm{b}}$ & $3.38^{\mathrm{c}}$ & 0.09 & 0.11 & 0.59 & 0.04 \\
\hline Fat, $\mathrm{kg} / \mathrm{d}$ & 1.24 & 0.86 & 1.11 & 0.84 & 0.04 & 0.07 & $<0.01$ & 0.12 \\
\hline SNF, $\%$ & 8.50 & 8.33 & 8.42 & 8.31 & 0.07 & 0.47 & 0.04 & 0.66 \\
\hline $\mathrm{SNF}, \mathrm{kg} / \mathrm{d}$ & 3.03 & 2.13 & 2.98 & 2.09 & 0.08 & 0.58 & $<0.01$ & 0.96 \\
\hline MUN, mg/dL & 8.99 & 11.26 & 9.15 & 10.78 & 0.26 & 0.56 & $<0.01$ & 0.22 \\
\hline $\mathrm{SCS}^{4}$ & 3.47 & 3.16 & 3.26 & 3.76 & 0.39 & 0.62 & 0.93 & 0.29 \\
\hline $\mathrm{BSA}, \mathrm{mg} / \mathrm{g}$ & 1.86 & 1.83 & 2.06 & 2.09 & 0.21 & 0.29 & 1.00 & 0.89 \\
\hline
\end{tabular}

\footnotetext{
${ }^{\mathrm{ac}}$ Superscripts a versus b: $P<0.05$. Superscripts b versus c: $P=0.06$.

${ }^{1} 3.5 \% \mathrm{FCM}=(0.4324 \times \mathrm{kg}$ of milk yield $)+(16.216 \times \mathrm{kg}$ of milk fat yield $)$.

${ }^{2} \mathrm{ECM}=(0.327 \times \mathrm{kg}$ of milk yield $)+(12.95 \times \mathrm{kg}$ of milk fat yield $)+(7.20 \times \mathrm{kg}$ of milk protein yield $)$.

${ }^{3}$ Feed efficiency $=$ ECM $(\mathrm{kg} / \mathrm{d}) / \mathrm{DMI}(\mathrm{kg} / \mathrm{d})$.

${ }^{4} \mathrm{SCS}=\log _{10}(\mathrm{SCC} / 12.5) / \log _{10} 2$.
} 

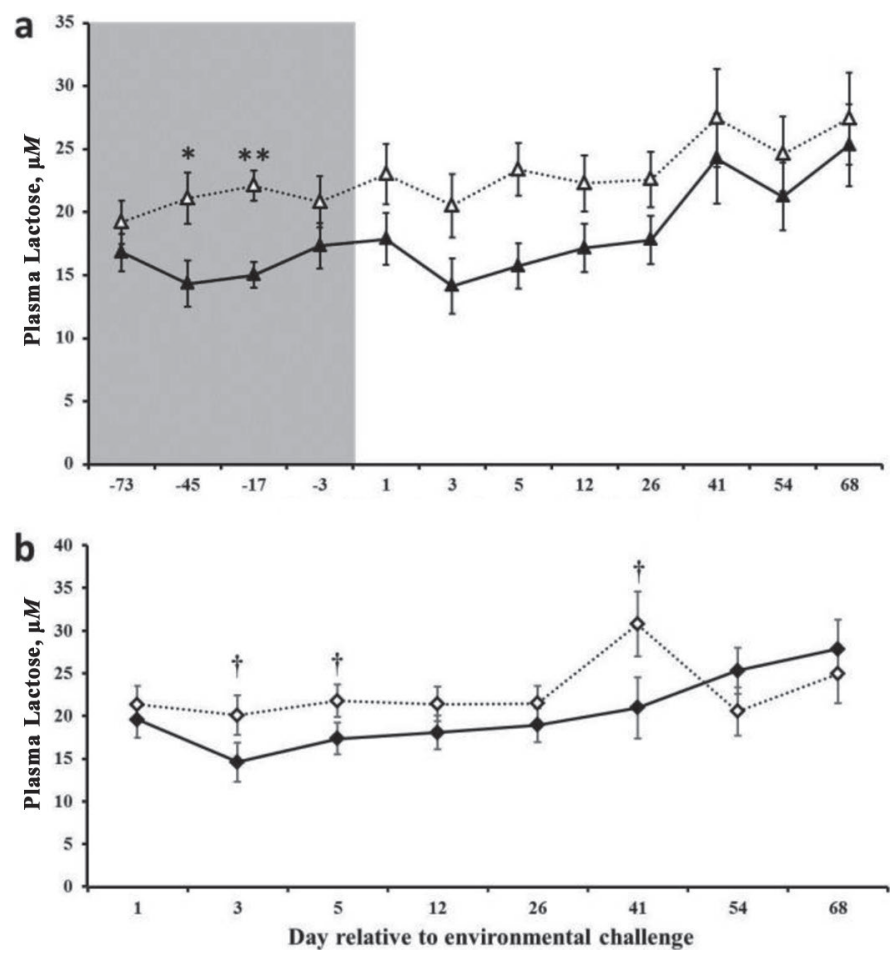

Figure 1. (a) Plasma concentrations of lactose in cows fed diets supplemented with Zn hydroxychloride $(\Delta ; \mathrm{n}=11)$ or Zn-Met $(\mathbf{\Lambda} ; \mathrm{n}$ $=12$ ) during the baseline (shaded area) and environmental challenge phases. (b) Plasma concentrations of lactose in cows with $(\checkmark ; \mathrm{n}=11)$ or without $(\diamond ; \mathrm{n}=12)$ cooling treatment during the environmental challenge phase. In the baseline phase, effect of $\mathrm{Zn}$ source $(P=0.03)$, time $(P=0.69)$, and $\mathrm{Zn}$ source $\times$ time interaction $(P=0.06)$. In the environmental challenge phase, effect of $\mathrm{Zn}$ source $(P=0.11)$, cooling $(P=0.36)$, time $(P<0.01)$, Zn source $\times$ cooling interaction $(P=$ $0.81)$, Zn source $\times$ time interaction $(P=0.52)$, cooling $\times$ time interaction $(P=0.09)$, and $\mathrm{Zn}$ source $\times$ cooling $\times$ time interaction $(P=$ 0.52). Error bars represent SEM. ${ }^{*} P<0.05$. ${ }^{* *} P<0.01 . \dagger P \leq 0.10$.

SCC in the present experiment, consistent with previous studies (Chan et al., 1997; Tarazón-Herrera et al., 1999). It has been suggested that summer weather is correlated with elevated SCC (Hammami et al., 2013) and increased mastitis incidences (Gaughan et al., 2009) on the farm level. However, controlled studies confirmed that HS per se does not increase milk SCC.

To the best of our knowledge, the current study is the first experiment to compare dietary Zn hydroxychloride with Zn-Met complex on the performance of lactating dairy cows under HS. Regardless of the environmental conditions, dietary Zn source had no effect on milk yield, DMI, and feed efficiency during the entire trial, suggesting that diets supplemented with IOZ or ZMC at a concentration of $75 \mathrm{mg} / \mathrm{kg}$ support similar performance during lactation in summer. In contrast, previous studies (Spears, 1996; Kellogg et al., 2004) reported that, relative to $\mathrm{ZnSO}_{4}$ or $\mathrm{Zn}$ oxide, feeding Zn-Met complex improved milk production. The advantage of Zn-AA complex over inorganic Zn sources to improve milk yield (Kellogg et al., 2004; Rabiee et al., 2010) was attributed to the increased bioavailability (Spears, 1996). Compared with Zn oxide, feeding Zn-Met complex does not alter $\mathrm{Zn}$ absorption but reduces urinal $\mathrm{Zn}$ excretion, resulting in a higher $\mathrm{Zn}$ retention (Spears, 1989). On the other hand, Genther and Hansen (2015) reported that supplementing sulfate-bound trace minerals $(\mathrm{Cu}, \mathrm{Mn}$, and $\mathrm{Zn})$, but not hydroxy minerals, reduced ruminal DM disappearance, suggesting that hydroxy minerals have no negative influences on rumen function compared with sulfate-bound trace minerals. However, direct comparisons between hydroxy trace mineral and mineral-AA complex on bioavailability and rumen functions in ruminants are still not available. The duration of the supplementation of different sources of Zn also influences the milk yield response of cows. In a meta-analysis, Rabiee et al. (2010) found that feeding Zn-AA complex starting before calving had a stronger effect on the increase in milk production than supplementation started after parturition. Using a ratio

Table 7. Gene expression in mammary tissue of cows fed diets supplemented with Zn hydroxychloride (IOZ) or Zn-Met complex (ZMC) either exposed to cooling (CL) or not exposed to cooling (NC)

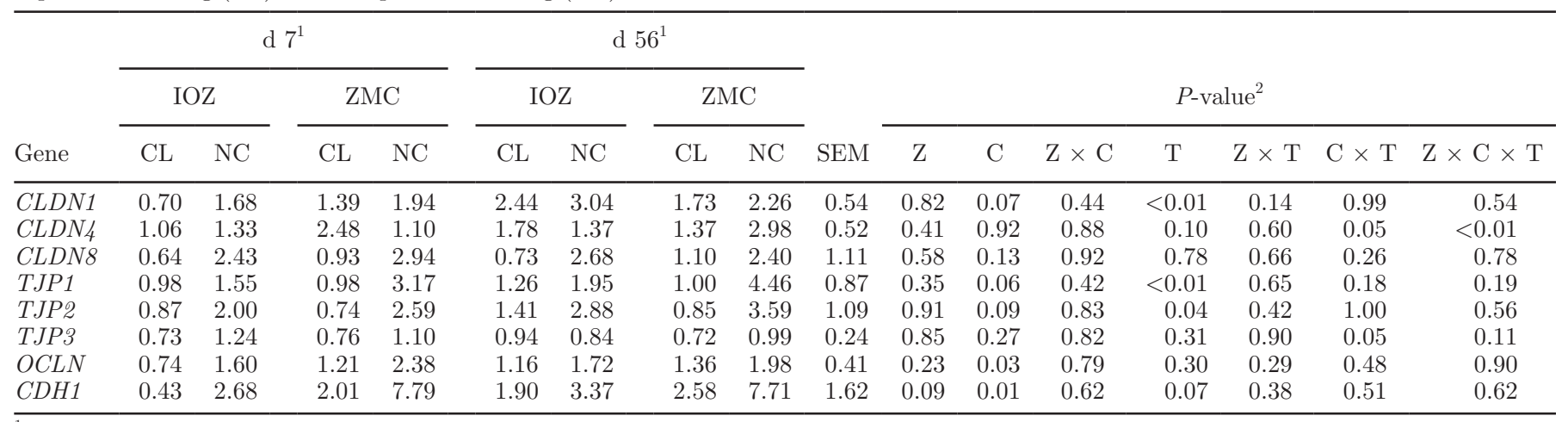

${ }^{1}$ Days relative to the onset of environmental challenge.

${ }^{2} \mathrm{Z}=\mathrm{Zn}$ source effect; $\mathrm{C}=$ cooling effect; $\mathrm{T}=$ time effect. 
WENG ET AL.
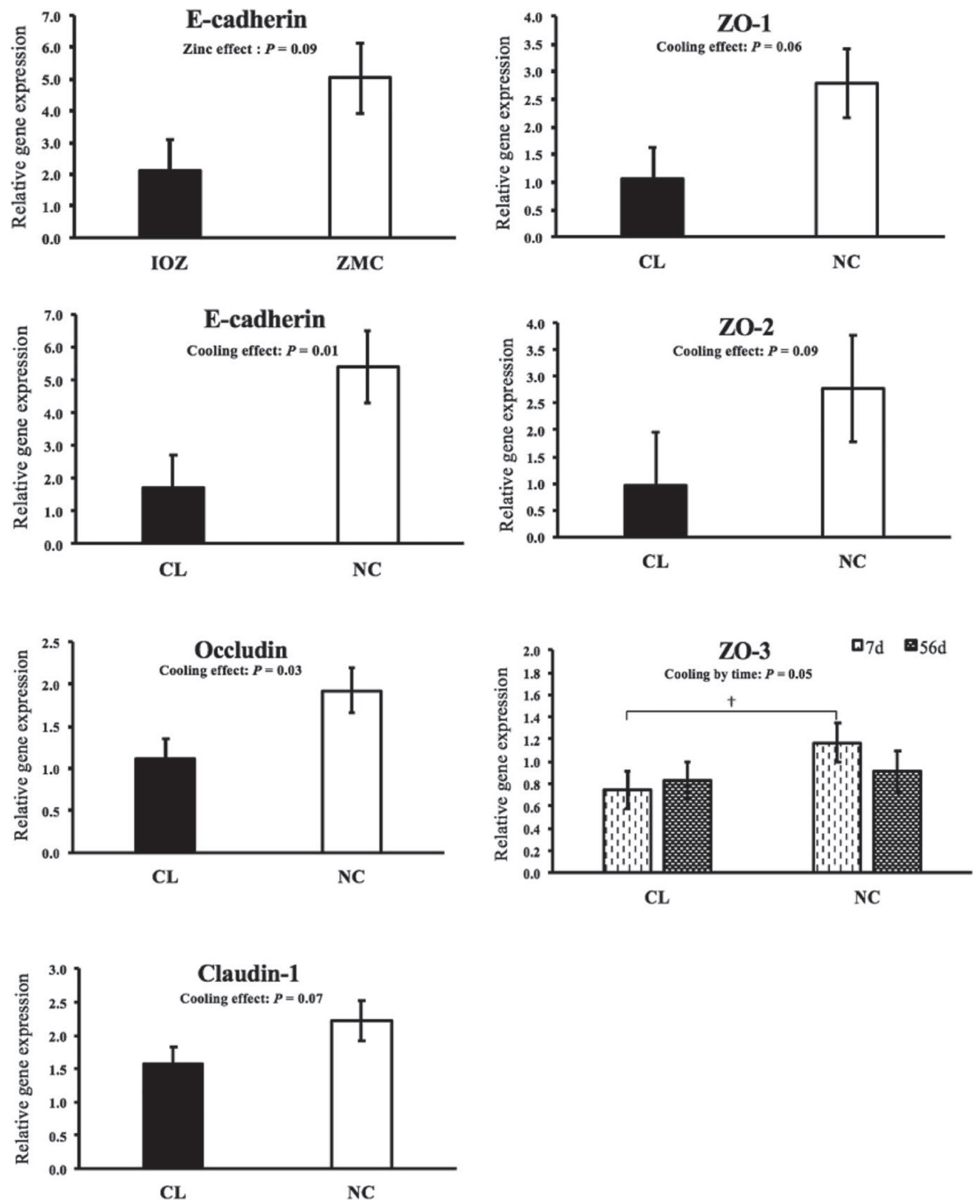

Figure 2. Relative gene expression of mammary tissue of cows fed diets supplemented with Zn hydroxychloride (IOZ, $\mathrm{n}=16)$ or Zn-Met complex $(\mathrm{ZMC}, \mathrm{n}=14)$ either exposed to cooling $(\mathrm{CL}, \mathrm{n}=16)$ or not exposed to cooling $(\mathrm{NC}, \mathrm{n}=14)$. ZO = zonula occludens. Data are provided based on the significance of gene expression analyses. Error bars represent SEM. 
of supplemental inorganic to organic $\mathrm{Zn}$ similar to that in the current experiment, Nayeri et al. (2014) reported that cows supplemented with $66.6 \mathrm{mg} / \mathrm{kg}$ of $\mathrm{ZnSO}_{4}$ and $8.4 \mathrm{mg} / \mathrm{kg}$ of Zn-AA complex $1 \mathrm{mo}$ before calving and $35 \mathrm{mg} / \mathrm{kg}$ of $\mathrm{ZnSO}_{4}$ and $40 \mathrm{mg} / \mathrm{kg}$ of $\mathrm{Zn}-\mathrm{AA}$ complex from calving until 250 DIM had $4.2 \%$ higher milk yield relative to those fed $75 \mathrm{mg} / \mathrm{kg}$ of $\mathrm{ZnSO}_{4}$. In contrast, the dietary treatments in the current study started during mid-lactation. Future studies are warranted to examine production responses of cows supplemented with hydroxy mineral and mineral-AA complex starting during the prepartum period. Moreover, most studies that
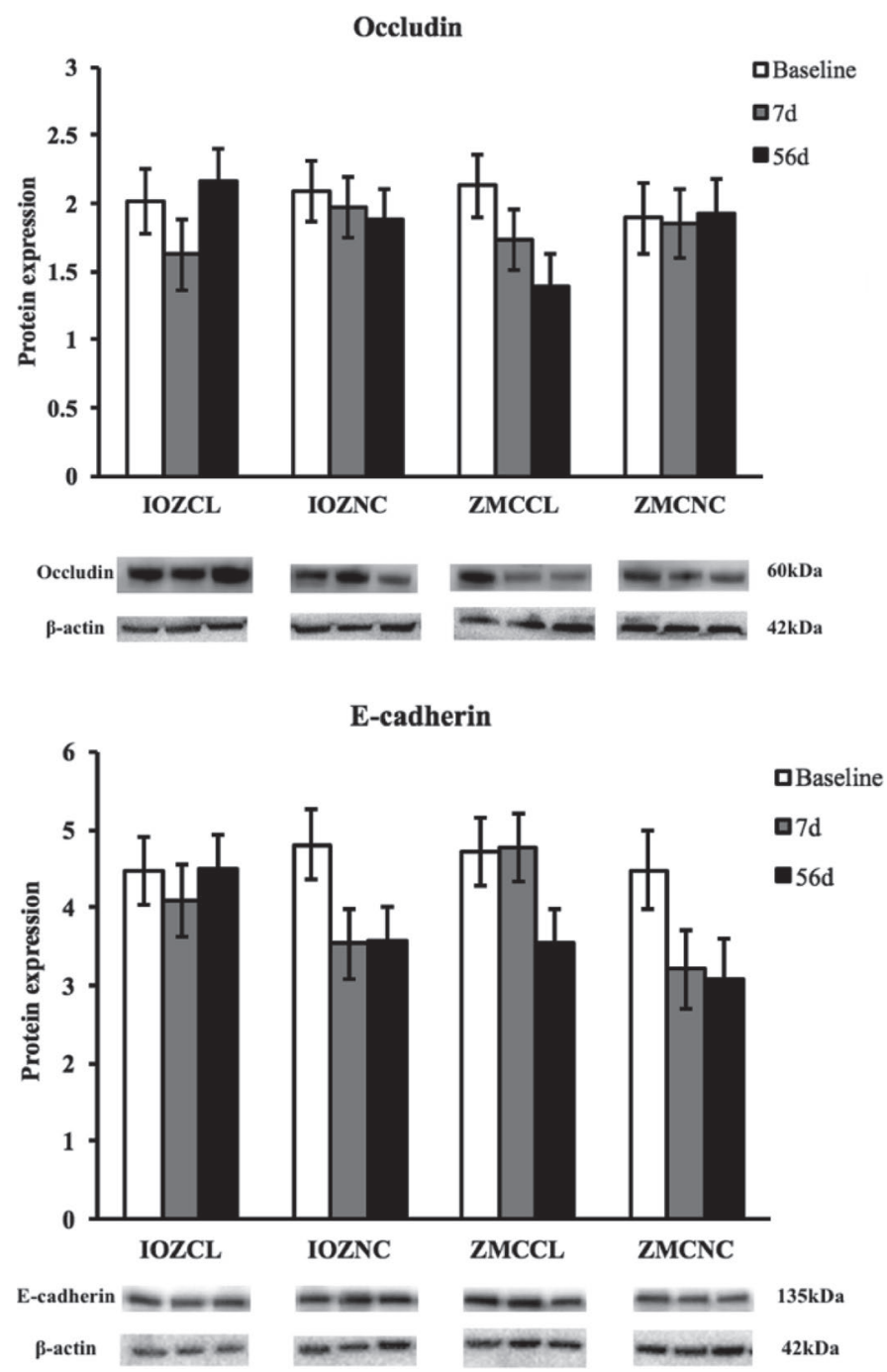

Figure 3. Protein expression of mammary tissue in cows fed diets supplemented with Zn hydroxychloride (IOZ, n = 16) or Zn-Met complex (ZMC, $\mathrm{n}=14$ ) either exposed to cooling (CL, $\mathrm{n}=16$ ) or not exposed to cooling $(\mathrm{NC}, \mathrm{n}=14)$. Data are presented as least squares means \pm standard error of the mean and displayed as the ratio of band intensity of each protein to loading control ( $\beta$-actin). No treatment effects or treatment $\times$ time interaction $(P \geq 0.12)$ were observed for occludin and E-cadherin protein expression. Error bars represent SEM. examine cows' responses to different $\mathrm{Zn}$ sources were conducted in temperate climates, and it is possible that different Zn sources affect cow performance differently under HS compared with thermoneutral condition.

Consistent with previous studies (Kellogg et al., 2004; Rabiee et al., 2010; Wang et al., 2013), Zn source had no influence on milk percentages of protein, lactose, and SNF. Different from Kellogg et al. (2004) and Nayeri et al. (2014), who reported that supplementation of Zn-Met or Zn-AA complexes reduced milk SCC compared with $\mathrm{ZnSO}_{4}$ or $\mathrm{Zn}$ oxide, in the current study the milk SCS was not influenced by dietary Zn sources. These data may indicate that replacing $40 \mathrm{mg} / \mathrm{kg}$ of $\mathrm{Zn}$ hydroxychloride with Zn-Met complex from $75 \mathrm{mg} / \mathrm{kg}$ of supplemental $\mathrm{Zn}$ has no effect on milk quality during summer. However, the total $\mathrm{Zn}$ content of diets used in the experiment conducted by Nayeri et al. (2014) and studies reviewed by Kellogg et al. (2004) was lower than that fed in the current study. It is possible that the high dietary Zn content fed in the present study prevented us from observing any potential effect of different $\mathrm{Zn}$ sources on milk SCC. Interestingly, cows fed ZMC had significantly lower milk fat concentration compared with those fed IOZ during the baseline phase, and ZMC CL cows had the lowest milk fat content among other treatment groups during the environmental challenge phase, suggesting that diets with ZMC may alter milk fat synthesis compared with IOZ, especially in cows in an evaporatively cooled environment. Reports on the effects of dietary $\mathrm{Zn}$ on milk fat concentration are inconsistent. As summarized by Kellogg et al. (2004) and Rabiee et al. (2010), supplementation of Zn-Met or Zn-AA complexes had no effect on milk fat percentage in lactating dairy cows. In contrast, Nayeri et al. (2014) observed that replacing $15.5 \mathrm{mg} / \mathrm{kg}$ of $\mathrm{ZnSO}_{4}$ with $\mathrm{Zn}$ AA complex in a lactating cow diet tended to decrease milk fat percentage compared with cows fed a control diet containing $75 \mathrm{mg} / \mathrm{kg}$ of $\mathrm{ZnSO}_{4}$. However, the diet supplemented with $40 \mathrm{mg} / \mathrm{kg}$ of Zn-AA complex and $35 \mathrm{mg} / \mathrm{kg}$ of $\mathrm{ZnSO}_{4}$ had no effect on milk fat content relative to the control. In the current study, the interaction between $\mathrm{Zn}$ source and environment also indicates that cows under HS may respond differently to diets containing different Zn sources, thus affecting milk fat synthesis. However, the underlying mechanisms are still unclear.

The mammary epithelium is unique in synthesizing and secreting milk components into the alveolar lumen, and this process requires the existence and maintenance of transepithelial transport pathways for milk synthesis (Stelwagen and Singh, 2014). A well-maintained mammary epithelial junction is an indicator of optimal mammary function, and loss of mammary epithelial integrity during lactation is related to reduced milk syn- 
thesis and secretion (Stelwagen and Singh, 2014). As reviewed by Shennan and Peaker (2000), plasma concentration of lactose is a preferable indicator to assess tightness or permeability of the mammary epithelium. In the present study, no environment and diet interaction was observed for plasma lactose concentration, indicating that HS and dietary zinc source influence the mammary epithelial barrier by different mechanisms. Environment had no overall effect on plasma lactose concentration, suggesting that cows under long-term exposure to HS largely maintain mammary epithelial integrity. However, NC cows tended to have higher plasma lactose concentrations at the beginning of the environmental challenge phase compared with CL cows. This indicates that the permeability of mammary cell junctions may temporarily increase when exposed to acute HS before returning to basal levels as adaptation to HS occurs. Similarly, Stelwagen et al. (1997) observed a gradual decrease in leakage of milk lactose in lactating cows with each cycle of extended milking interval, which suggests that the mammary gland is able to adapt to altered milk frequency, possibly by reorganizing mammary epithelial junctions. The reason for the transient increase in plasma lactose concentration of $\mathrm{NC}$ cows relative to $\mathrm{CL}$ cows at $41 \mathrm{~d}$ of the environmental challenge phase is unclear. All cows were managed and handled similarly during the entire trial.

Compared with IOZ cows, ZMC cows had lower plasma concentration of lactose during both baseline and environmental challenge phases, suggesting that replacing $40 \mathrm{mg} / \mathrm{kg}$ of Zn-hydroxychloride with Zn-Met in the diet reduces the leakage of lactose through mammary epithelial barriers. Dietary Zn is a critical micronutrient in the maintenance of epithelial barrier integrity. In vitro depletion of zinc, in the medium of a human intestinal Caco-2 cell culture, significantly increased epithelial permeability, whereas repletion of $\mathrm{Zn}$ into the culture rescued the leaky epithelial barrier (Finamore et al., 2008). Similarly, supplementing Zn into a porcine renal LLC-PK cell line culture reduced epithelial permeability (Wang et al., 2014), indicating a conservation of the critical role of $\mathrm{Zn}$ in maintaining epithelial integrity across species and cell types. In vivo, increasing dietary Zn concentration from 120 to $220 \mathrm{mg} / \mathrm{kg}$ by supplementation of Zn-AA complex attenuated the increase in ileal permeability caused by HS in growing pigs (Sanz Fernandez et al., 2014). Interestingly, replacing a portion of $\mathrm{ZnSO}_{4}$ with $\mathrm{Zn}$-AA complex in the swine diet also improved the integrity of the ileal epithelium under HS conditions (Pearce et al., 2015), suggesting a better performance of $\mathrm{Zn}-\mathrm{AA}$ complex over $\mathrm{ZnSO}_{4}$ to maintain epithelial integrity, possibly due to the higher bioavailability (Spears, 2003). Nevertheless, the differences in plasma lactose between $\mathrm{Zn}$ source obtained in the current study provide evidence that dietary $\mathrm{Zn}$ source also influences mammary epithelial integrity in lactating dairy cows. In addition, replacing $40 \mathrm{mg} / \mathrm{kg}$ of Zn hydroxychloride with Zn-Met reduces permeability of the mammary epithelium. Interestingly, milk BSA content was not affected by environmental conditions, dietary Zn source, or their interactions. Under normal physiological conditions, similar to immunoglobulin, serum albumin is transported across mammary epithelial cells through a transcytosis pathway in mouse lactating mammary gland (Monks and Neville, 2004). However, when the mammary epithelial barrier is disrupted, milk BSA content is dramatically increased due to influx from blood into milk through the paracellular pathways (Stelwagen and Singh, 2014). Therefore, data in the present study indicate that environmental and dietary treatments only altered permeability of the mammary epithelium but did not result in a disruption of the mammary epithelial barrier.

The paracellular barrier of the epithelium comprises a junctional complex including the tight junction, adherens junction, and desmosome (reviewed by Itoh and Bissell, 2003; Tsukita et al., 2008; Turner, 2009). The tight junction is located at the apical side of cell-cell junction and is the rate-limiting structure regulating epithelial permeability (Turner, 2009). It comprises transmembrane-spanning structural protein families, including occludin and claudins, that are linked to the intracellular actin cytoskeleton via scaffolding proteins, the ZO family (Stelwagen and Singh, 2014). The adherens junction is adjacent to the tight junction and is critical for cell-to-cell adhesion and polarization (Itoh and Bissell, 2003; Turner, 2009). The main transmembrane protein that forms the adherens junction between epithelial cells is E-cadherin (Knudsen and Wheelock, 2005). In the current study, compared with CL cows, the mammary gland of $\mathrm{NC}$ cows had higher gene expression of occludin, claudin $1, \mathrm{ZO} 1$ and $\mathrm{ZO} 2$, and E-cadherin at both 7 and $56 \mathrm{~d}$ of the environmental challenge phase, suggesting an overall increase in synthesis of protein related to the paracellular junction. The trend for increased gene expression of ZO 3 at 7 but not $56 \mathrm{~d}$ perhaps indicates that the effort to synthesize more mammary tight junction proteins is stronger when a cow is exposed to acute HS. Similarly, in gilts, exposure to $\mathrm{HS}$ for $7 \mathrm{~d}$ increased gene expression of occludin, claudin 3, and ZO 1 in the jejunum (Pearce et al., 2013). Interestingly, although mammary gene expressions are upregulated more in $\mathrm{NC}$ cows than in CL cows, protein expression of occludin and E-cadherin was not influenced by environment. This is consistent with the similar plasma lactose concentration between $\mathrm{NC}$ and CL cows and confirms that cows under HS are able to maintain mammary epithelial integrity. 
Furthermore, these data may suggest that there is a net loss of junctional proteins due to HS and that the mammary gland of $\mathrm{NC}$ cows strives to maintain normal epithelial integrity by synthesizing more proteins relative to CL cows. Therefore, resources (e.g., AA) and energy (e.g., ATP) in the mammary gland may shift from milk synthesis to maintain proper epithelial integrity, which may be one mechanism leading to reduced milk production of HS lactating dairy cows.

Surprisingly, although cows supplemented with ZMC had lower plasma lactose concentration than cows supplemented with IOZ, no differences were observed between Zn sources for gene and protein expressions of most epithelial junction proteins examined. Similar to the results in the current study, Pearce et al. (2015) reported that replacing $60 \mathrm{mg} / \mathrm{kg}$ of $\mathrm{ZnSO}_{4}$ with $\mathrm{Zn}$ AA complex in gilts' diet partially alleviated increases in intestinal permeability after $12 \mathrm{~h}$ of exposure to HS without influencing gene expression of tight junction proteins compared with feeding $120 \mathrm{mg} / \mathrm{kg}$ of $\mathrm{ZnSO}_{4}$. Relative to those in the Zn-enriched medium, human intestinal Caco-2 cells cultured in a Zn-depleted medium display reduced protein expression of occludin and $\mathrm{ZO} 1$ and reorganization of tight and adherens junctional proteins from epithelial junctions to cytoplasm (Finamore et al., 2008). These data may indicate that $\mathrm{Zn}$ affects epithelial junctions via maintaining the expression and proper location of tight and adherens junctional proteins. Therefore, it is possible that replacing $40 \mathrm{mg} / \mathrm{kg}$ of dietary Zn-hydroxychloride with ZnMet promotes proper locations of junctional proteins between mammary epithelial cells without affecting their expression compared with IOZ, thereby improving mammary epithelial integrity. The mechanism for increased gene expression of E-cadherin in ZMC cows compared with IOZ cows is unknown. As reviewed by Oloumi et al. (2004), there are 3 E-box motifs located at the $5^{\prime}$ promoter region of the gene of E-cadherin, which can be bound by Zn finger proteins to regulate its expression. Zinc is the intrinsic component of $\mathrm{Zn}$ finger proteins and influences their stability to regulate gene expression (reviewed by Lee and Kelleher, 2016). Thus, different sources of dietary Zn may alter cellular activity of Zn finger proteins to influence gene expression. The fact that dietary Zn source affects mammary E-cadherin expression at the transcription level but not at the translational level may indicate a posttranscriptional regulation of E-cadherin, but the mechanism is still unclear.

\section{CONCLUSIONS}

Deprivation of cooling remarkably impaired lactation performance of dairy cows, but $\mathrm{NC}$ cows largely maintained mammary epithelial integrity compared with CL cows. The protein expression of occludin and E-cadherin was not altered by environment. However, NC cows had higher gene expression of epithelial junctional proteins, indicating that HS induces epithelial junctional protein synthesis to maintain proper epithelial integrity. On the other hand, replacing $40 \mathrm{mg} /$ $\mathrm{kg}$ of $\mathrm{Zn}$ hydroxychloride with Zn-Met complex in the diet of lactating cows had no strong effects on cow performance but reduced plasma lactose concentration. These data suggest that dietary Zn-Met complex may enhance mammary epithelial integrity, but the cellular mechanism is still unclear.

\section{ACKNOWLEDGMENTS}

The authors thank the staff of the Dairy Research Center of the University of Georgia (Tifton, GA) for animal care and data collection. This project was supported by Zinpro Corporation (Eden Prairie, MN).

\section{REFERENCES}

Abuajamieh, M., S. K. Kvidera, E. A. Horst, E. J. Mayorga, J. T. Seibert, J. S. Johnson, J. W. Ross, M. A. Al-Qaisi, P. J. Gorden, J. DeFrain, R. P. Rhoads, and L. H. Baumgard. 2016. The effects of zinc amino acid complex on biomarkers of gut integrity and metabolism in heat-stressed steers. J. Anim. Sci. 94:564. (Abstr.)

Capuco, A. V., S. E. Ellis, S. A. Hale, E. Long, R. A. Erdman, X. Zhao, and M. J. Paape. 2003. Lactation persistency: Insights from mammary cell proliferation studies. J. Anim. Sci. 81(Suppl. 3):18-31.

Chan, S. C., J. T. Huber, K. H. Chen, J. M. Simas, and Z. Wu. 1997. Effects of ruminally inert fat and evaporative cooling on dairy cows in hot environmental temperatures. J. Dairy Sci. 80:1172-1178.

Chandan, R. C. 2006. Milk composition, physical and processing characteristics. Pages 347-377 in Handbook of Food Products Manufacturing. Y. H. Hui, R. C. Chandan, S. Clark, N. Cross, J. Dobbs, W. J. Hurst, L. M. L. Nollet, E. Shimoni, N. Sinha, E. B. Smith, S. Surapat, and F. Toldrá, ed. Wiley, Hoboken, NJ.

Chen, K. H., J. T. Huber, C. B. Theurer, D. V. Armstrong, R. C. Wanderley, J. M. Simas, S. C. Chan, and J. L. Sullivan. 1993. Effect of protein quality and evaporative cooling on lactational performance of Holstein cows in hot weather. J. Dairy Sci. 76:819-825.

Collier, R. J., G. E. Dahl, and M. J. VanBaale. 2006. Major advances associated with environmental effects on dairy cattle. J. Dairy Sci. $89: 1244-1253$.

Dikmen, S., and P. J. Hansen. 2009. Is the temperature-humidity index the best indicator of heat stress in lactating dairy cows in a subtropical environment? J. Dairy Sci. 92:109-116.

Dokladny, K., M. N. Zuhl, and P. L. Moseley. 2016. Intestinal epithelial barrier function and tight junction proteins with heat and exercise. J. Appl. Physiol. 120:692-701.

Farr, V. C., K. Stelwagen, L. R. Cate, A. J. Molenaar, T. B. McFadden, and S. R. Davis. 1996. An improved method for the routine biopsy of bovine mammary tissue. J. Dairy Sci. 79:543-549.

Finamore, A., M. Massimi, L. Conti Devirgiliis, and E. Mengheri. 2008. Zinc deficiency induces membrane barrier damage and increases neutrophil transmigration in Caco-2 cells. J. Nutr. 138:1664-1670.

Gaughan, J., N. Lacetera, S. E. Valtorta, H. H. Khalifa, L. Hahn, and T. Mader. 2009. Response of domestic animals to climate challenges. Pages 131-170 in Biometeorology for Adaptation to Climate Variability and Change. K. L. Ebi, I. Burton, and G. R. McGregor, ed. Springer Netherlands, Dordrecht, the Netherlands. 
Genther, O. N., and S. L. Hansen. 2015. The effect of trace mineral source and concentration on ruminal digestion and mineral solubility. J. Dairy Sci. 98:566-573.

Hammami, H., J. Bormann, N. M'hamdi, H. H. Montaldo, and N. Gengler. 2013. Evaluation of heat stress effects on production traits and somatic cell score of Holsteins in a temperate environment. J. Dairy Sci. 96:1844-1855.

Itoh, M., and M. J. Bissell. 2003. The organization of tight junctions in epithelia: Implications for mammary gland biology and breast tumorigenesis. J. Mammary Gland Biol. Neoplasia 8:449-462.

Kadzere, C. T., M. R. Murphy, N. Silanikove, and E. Maltz. 2002 Heat stress in lactating dairy cows: A review. Livest. Prod. Sci. $77: 59-91$.

Kellogg, D. W., D. J. Tomlinson, M. T. Socha, and A. B. Johnson. 2004. Effects of zinc methionine complex on milk production and somatic cell count of dairy cows: Twelve-trial summary. Prof. Anim. Sci. 20:295-301.

Knudsen, K. A., and M. J. Wheelock. 2005. Cadherins and the mammary gland. J. Cell. Biochem. 95:488-496.

Lee, S., and S. L. Kelleher. 2016. Molecular regulation of lactation: The complex and requisite roles for zinc. Arch. Biochem. Biophys. 611:86-92.

Lieske, B., A. Jantz, and B. Finke. 2005. An improved analytical approach for the determination of bovine serum albumin in milk. Dairy Sci. Technol. 85:237-248.

Monks, J., and M. C. Neville. 2004. Albumin transcytosis across the epithelium of the lactating mouse mammary gland. J. Physiol. 560:267-280

Nayeri, A., N. C. Upah, E. Sucu, M. V. Sanz-Fernandez, J. M. DeFrain, P. J. Gorden, and L. H. Baumgard. 2014. Effect of the ratio of zinc amino acid complex to zinc sulfate on the performance of Holstein cows. J. Dairy Sci. 97:4392-4404.

Nguyen, D. A., and M. C. Neville. 1998. Tight junction regulation in the mammary gland. J. Mammary Gland Biol. Neoplasia 3:233246

NRC. 2001. Nutrient Requirements of Dairy Cattle. 7th rev. ed. Natl. Acad. Press, Washington, DC.

Oloumi, A., T. McPhee, and S. Dedhar. 2004. Regulation of E-cadherin expression and beta-catenin/Tcf transcriptional activity by the integrin-linked kinase. Biochim. Biophys. Acta 1691:1-15.

Pearce, S. C., V. Mani, T. E. Weber, R. P. Rhoads, J. F. Patience, L. H. Baumgard, and N. K. Gabler. 2013. Heat stress and reduced plane of nutrition decreases intestinal integrity and function in pigs. J. Anim. Sci. 91:5183-5193.

Pearce, S. C., M. V. Sanz-Fernandez, J. H. Hollis, L. H. Baumgard, and N. K. Gabler. 2014. Short-term exposure to heat stress attenuates appetite and intestinal integrity in growing pigs. J. Anim. Sci. 92:5444-5454

Pearce, S. C., M. V. Sanz Fernandez, J. Torrison, M. E. Wilson, L. H Baumgard, and N. K. Gabler. 2015. Dietary organic zinc attenuates heat stress-induced changes in pig intestinal integrity and metabolism. J. Anim. Sci. 93:4702-4713.

Pereira, P. C. 2014. Milk nutritional composition and its role in human health. Nutrition 30:619-627.

Rabiee, A. R., I. J. Lean, M. A. Stevenson, and M. T. Socha. 2010. Effects of feeding organic trace minerals on milk production and reproductive performance in lactating dairy cows: A meta-analysis. J. Dairy Sci. 93:4239-4251.

Rhoads, M. L., R. P. Rhoads, M. J. VanBaale, R. J. Collier, S. R. Sanders, W. J. Weber, B. A. Crooker, and L. H. Baumgard. 2009. Effects of heat stress and plane of nutrition on lactating Holstein cows: I. Production, metabolism, and aspects of circulating somatotropin. J. Dairy Sci. 92:1986-1997.

Sanz Fernandez, M. V., S. C. Pearce, N. K. Gabler, J. F. Patience, M. E. Wilson, M. T. Socha, J. L. Torrison, R. P. Rhoads, and L. H. Baumgard. 2014. Effects of supplemental zinc amino acid complex on gut integrity in heat-stressed growing pigs. Animal 8:43-50.

Shennan, D. B., and M. Peaker. 2000. Transport of milk constituents by the mammary gland. Physiol. Rev. 80:925-951.

Shwartz, G., M. L. Rhoads, M. J. VanBaale, R. P. Rhoads, and L. H. Baumgard. 2009. Effects of a supplemental yeast culture on heatstressed lactating Holstein cows. J. Dairy Sci. 92:935-942.

Spears, J. W. 1989. Zinc methionine for ruminants: Relative bioavailability of zinc in lambs and effects of growth and performance of growing heifers. J. Anim. Sci. 67:835-843.

Spears, J. W. 1996. Organic trace minerals in ruminant nutrition. Anim. Feed Sci. Technol. 58:151-163.

Spears, J. W. 2003. Trace mineral bioavailability in ruminants. J. Nutr. 133:1506S-1509S

Stelwagen, K., V. C. Farr, H. A. McFadden, C. G. Prosser, and S. R. Davis. 1997. Time course of milk accumulation-induced opening of mammary tight junctions, and blood clearance of milk components. Am. J. Physiol. 273:R379-R386.

Stelwagen, K., and K. Singh. 2014. The role of tight junctions in mammary gland function. J. Mammary Gland Biol. Neoplasia 19:131138.

Tarazón-Herrera, M., J. T. Huber, J. Santos, H. Mena, L. Nusso, and C. Nussio. 1999. Effects of bovine somatotropin and evaporative cooling plus shade on lactation performance of cows during summer heat stress. J. Dairy Sci. 82:2352-2357.

Taylor, R. B., J. T. Huber, R. A. Gomez-Alarcon, F. Wiersma, and X. Pang. 1991. Influence of protein degradability and evaporative cooling on performance of dairy cows during hot environmental temperatures. J. Dairy Sci. 74:243-249.

Tsukita, S., Y. Yamazaki, T. Katsuno, A. Tamura, and S. Tsukita. 2008. Tight junction-based epithelial microenvironment and cell proliferation. Oncogene 27:6930-6938.

Turner, J. R. 2009. Intestinal mucosal barrier function in health and disease. Nat. Rev. Immunol. 9:799-809.

Wang, R. L., J. G. Liang, L. Lu, L. Y. Zhang, S. F. Li, and X. G. Luo. 2013. Effect of zinc source on performance, zinc status, immune response, and rumen fermentation of lactating cows. Biol. Trace Elem. Res. 152:16-24.

Wang, X., M. C. Valenzano, J. M. Mercado, E. P. Zurbach. C. J. Flounders, and J. M. Mullin. 2014. Zinc enhancement of LLCPK(1) renal epithelial barrier function. Clin. Nutr. 33:280-286.

West, J. W. 2003. Effects of heat stress on production in dairy cattle. J. Dairy Sci. 86:2131-2144.

Wheelock, J. B., R. P. Rhoads, M. J. Vanbaale, S. R. Sanders, and L. H. Baumgard. 2010. Effects of heat stress on energetic metabolism in lactating Holstein cows. J. Dairy Sci. 93:644-655.

Wildman, E. E., G. M. Jones, P. E. Wagner, R. L. Boman, H. F. Troutt Jr., and T. N. Lesch. 1982. A dairy cow body condition scoring system and its relationship to selected production characteristics. J. Dairy Sci. 65:495-501.

Zimbelman, R. B., R. P. Rhoads, M. L. Rhoads, G. C. Duff, L. H. Baumguard, and R. J. Collier. 2009. A re-evaluation of the impact of temperature humidity index and black globe temperature humidity index (BGHI) on milk production in high producing dairy cows. Pages 158-168 in Proc. 24th Southwest Nutr. Man. Conf. Tempe, AZ. University of Arizona, Tucson. 